\title{
Konseptualisasi Perang Badar sebagai Strategi Bisnis
}

\author{
Idil Rakhmat Susanto ${ }^{1}$, Tjiptohadi Sawarjuwono ${ }^{2}$ \\ ${ }^{1}$ Universitas Muhammadiyah Makassar, Email: idil.rahmat@unismuh.ac.id \\ ${ }^{2}$ Universitas Airlangga, Email: tjiptohadi@feb.unair.ac.id
}

\begin{abstract}
Abstrak
Studi ini bertujuan untuk menguraikan keterkaitan strategi perang Badar dengan strategi perusahaan. Strategi perang Badar merupakan strategi berbasis sumber daya yang dianggap dapat menjadi landasan bagi perusahaan untuk menerapkan strategi dalam menghadapi persaingan guna meningkatkan kinerja perusahaan. Teori yang digunakan sebagai acuan studi ini adalah Resource Based Theory (RBT) terkait pemanfaatan sumber daya perusahaan. Metode penulisan menggunakan deskriptif kualitatif dengan pendekatan studi kepustakaan untuk mencari referensi terkait filosofi perang badar untuk menjelaskan keterkaitannya dengan strategi perusahaan. Hasil dari studi ini menjelaskan bagaimana strategi perang Badar memiliki keterkaitan dan relevansi dengan strategi perusahaan yang berlaku saat ini. Strategi perang badar sangat sesuai jika digunakan sebagai landasan penerapan strategi berbasis sumber daya bagi perusahaan sekalipun perusahaan tersebut memiliki sumber daya yang terbatas. Strategi perang Badar yang dipimpin oleh Rasulullah dapat dijadikan sebagai teladan bagi manajer dalam menerapkan strategi berbasis sumber daya dengan memaksimalkan dan meningkatkan kemampuan sumber daya yang ada serta menempatkan sumber daya tersebut pada posisi yang sesuai dengan kemampuannya masing-masing.
\end{abstract}

Kata kunci : Strategi perang badar; strategi perusahaan; sumber daya; kinerja perusahaan

\section{Abstract}

This study aims to describe the relationship between Badar's war strategy and corporate strategy. Badar war strategy is a resource-based strategy that is considered to be a foundation for companies to implement strategies in dealing with competition to improve company performance. The theory used as a reference for this study is Resource based theory related to the utilization of company resources. This study using descriptive qualitative literature study approach to look for references related to the philosophy of Badar war to explain its relationship with corporate strategy. The results of this study explain how Badar's war strategy has relevance 
to the current corporate strategy. Badar war strategy is very suitable if it is used as a basis for implementing a resource-based strategy for the company even though the company has limited resources. The Badr war strategy led by Rasulullah can be used as a role model for managers in implementing resource-based strategies by maximizing and enhancing the capabilities of existing resources and placing these resources in a position suitable to their respective abilities.

Keywords: Badar's war strategy; firm strategy; resources; firm performance

\section{Pendahuluan}

Strategi merupakan cara unik yang dilakukan perusahaan agar mampu mencapai tujuan yang telah ditetapkan yaitu kinerja perusahaan (Collins, 2020; Porter, 1985). Bentuk strategi berbeda-beda tergantung kebutuhan dan kemampuan suatu perusahaan dalam mengikuti persaingan (Parnell \& Brady, 2019; Chong \& Chong, 1997). Ketika perusahaan gagal memilih strategi yang sesuai maka akan berdampak sistemik pada kinerja dan keberlanjutan suatu perusahaan (Grimmer et al, 2017; Stede, et al, 2006).

Studi tentang pentingnya penerapan berbagai macam konsep strategi dalam meningkatkan kinerja baik perusahaan maupun organisasi nonprofit telah banyak menarik banyak perhatian para peneliti misalnya: Grimmer et al (2017); Lorenzo et al (2018); Lu \& Huang (2019); Saepudin \& Mukarromah (2018); Encep \& Cahyani (2016) dan Pasch (2019). Secara umum hasil penelitian menyatakan bahwa faktor utama yang dapat menunjang keberhasilan suatu perusahaan adalah terletak pada penerapan strategi yang tepat, sesuai kemampuan sumberdaya yang dimiliki perusahaan untuk mencapai keunggulan kompetitif. Dengan penerapan strategi yang efektif maka pencapaian tujuan kinerja dapat terpenuhi secara optimal serta mampu menjaga keberlanjutan perusahaan menghadapi persaingan bisnis dalam jangka panjangBeberapa penelitian sebelumnya telah melakukan pengujian mengenai berbagai alternatif strategi yang tepat pada perusahaan sebagai solusi untuk menghadapi persaingan, misalnya strategi berbasis sumberdaya khusus perusahaan retail (Grimmer et al, 2017), strategi berbasis pelayanan (Wilden \& Gudergan, 2017), flekibilitas dan inovasi (Xiu et al, 2017), dan strategi berbasis pemasaran (Saepudin \& Mukarromah, 2018). Namun disisi lain hingga saat ini masih saja terjadi kasus-kasus kegagalan perusahaan dalam mengikuti persaingan pasar global yang tak lain disebabkan ketidakmampuan perusahaan dalam memilih strategi yang sesuai sehingga mengakibatkan keggagalan dalam bersaing 
dan berakhir bangkrut. Adapun beberapa perusahaan yang mengalami kegagalan seperti, Sears (2018); Toys R US (2019); Thomas Cook (2019); Forever 21 (2019) dan di Indonesia, Batavia Air (2013); Tiga Pilar Sejahtera Group (2017); Sari Wangi (2018). Kegagalan ini terjadi karena strategi yang diterapkan masih bersifat umum dan tidak memiliki keunikan, selain itu perusahaan tidak mampu mengidentifikasi lingkungan bisnis dan kurang mampu mengenal kemampuan para pesaing sehingga kemungkinan strategi yang diterapkan sudah ketinggalan dan sudah terlambat untuk mengejar ketertinggalan tersebut. Ini menjadi masalah penting bagi keberlanjutan perusahaan sehingga perlu mendapat perhatian yang penuh bagi perusahaan khususnya manajer dalam mengatisipasi segala kemungkinan resiko terburuk yang akan dihadapi oleh perusahaan (Collins, 2020).

Berdasarkan realitas fenomena atas masalah yang dialami perusahaan dalam persaingan bisnis, maka studi ini mencoba memberikan wawasan baru dengan memperkenalkan satu strategi bisnis yang unik sebagai solusi untuk mengatasi ketidakmampuan dan berbagai keterbatasan yang dimiliki perusahaan yang dapat menghambat perkembangan dalam bersaing yaitu strategi perang Badar. Strategi perang Badar merupakan strategi yang dapat diterapkan pada perusahaan dan dapat menjadi solusi bagi kelemahan strategi yang diterapkan perusahaan karena telah terbukti berhasil dilakukan pada masanya. Perang Badar yang pada waktu itu dipimpin oleh Rasulullah Muhammad Sallallahu Alaihi Wasallam ternyata mampu dimenangkan karena beliau menerapkan strategi perang berbasis sumberdaya yang sangat efektif meskipun jumlah pasukan lebih sedikit dibandingkan musuh. Jika dikaitkan dengan strategi perusahaan maka strategi perang dapat diibaratkan sebagai strategi perusahaan untuk menghadapi persaingan bisnis, dan kemenangan dalam peperangan dapat diibaratkan sebagai pencapaian kinerja yang optimal bagi suatu perusahaan.

Studi ini merupakan penelitian kualitatif dengan pendekatan deskriptif yang bertujuan untuk menguraikan bagaimana strategi perang Badar dapat dikaitkan dengan strategi perusahaan di era modern saat ini, sehingga dapat digunakan perusahaan dalam hal pemilihan dan penerapan strategi yang tepat untuk meningkatkan kinerja perusahaan. Jika kita melihat secara sederhana, tentu akan timbul pertanyaan apa keterkaitan perang Badar dengan strategi perusahaan, sementara keduanya merupakan hal yang sangat berbeda. Studi ini 
menganggap bahwa perang Badar mengandung makna filsafat terkait strategi berbasis sumber daya yang dapat diterapkan pada perusahaan. Al Kindi dalam pemikirannya menyatakan bahwa ilmu pengetahuan dan agama merupakan sesuatu yang tidak dapat dipisahkan, seperti halnya pemikiran yang dibahas dalam studi ini tentang bagaimana sejarah dari perang Badar mengandung filosofi strategi perang yang memiliki keterkaitan dengan strategi bisnis yang dilakukan oleh perusahaan. Sawarjuwono (1997) menjelaskan bahwa praktik akuntansi dan pemikiran akuntansi tidak dapat dipandang pada perspektif konvensional dan fungsional saja, akan tetapi perlu melihat perspektif lain yang berkaitan dengan dimana akuntasi itu diterapkan misalnya penggunaan perspektif peradaban Islam dalam praktik akuntansi. Jika kita menelusuri sejarah peradaban Islam yaitu pada masa perang Badar dimana pada waktu itu perang dipimpin langsung oleh Rasulullah bersama para sahabatnya, kondisi tersebut secara konseptual memiliki relevansi dengan kondisi perusahaan khususnya terkait dengan strategi bisnis yang dilakukan perusahaan saat ini.

Secara eksplisit studi ini juga bertujuan untuk memberikan wawasan bahwa kehadiran Rasulullah di muka bumi ini merupakan rahmat bagi seluruh alam semesta pada berbagai konteks kehidupan. Selanjutnya studi ini akan disusun mulai dari: Resources Based Theory; strategi perusahaan; strategi perang Badar; keterkaitan strategi perusahaan dan strategi perang Badar; dan kesimpulan. Hasil dari studi ini diharapkan mampu memberi wawasan baru secara praktis mengenai penerapan strategi perang Badar pada perusahaan yang dapat menjadi faktor pendukung utama dalam peningkatan kinerja yang bahkan jika perusahaan tersebut memiliki sumber daya yang terbatas. Meskipun perusahaan memiliki keterbatasan, namun jika sumber daya yang ada mampu dimanfaatkan sebaik mungkin maka akan menghasilkan kinerja yang lebih baik.

\section{Metode}

Studi ini merupakan studi pemikiran yang menggunakan metode deskriptif dengan pendekatan kualitatif untuk menjelaskan keterkaitan antara strategi perang badar dengan strategi perusahaan. Metode kepustakaan dan survei literatur dokumentatif melalui jurnal dan buku dalam bentuk publikasi online. Metode ini digunakan untuk mencari informasi dari berbagai literatur yang mengkaji tentang filosofi dari sejarah perang badar dan juga mengenai konsep-konsep penerapan 
strategi perusahaan. Kemudian hasil dari pengumpulan informasi digunakan untuk menjelaskan keterkaitan antara filosofi perang badar sebagai suatu strategi dengan konseptualisasi penerapan strategi perusahaan berbasis sumberdaya.

\section{Hasil dan Pembahasan}

\section{Resources Based Theory}

Resource Based Theory (RBT) berfokus dalam menjelaskan kemampuan perusahaan menganalisis dan menafsirkan sumber daya untuk memahami bagaimana perusahaan mampu unggul dalam persaingan. RBT berfokus pada konsep karakter perusahaan yang tidak mudah direplikasi sebagai sumber kinerja yang unggul kompetitif. Sumber daya yang tidak dapat dengan mudah ditransfer atau dibeli, yang memerlukan proses belajar yang panjang atau perubahan besar dalam iklim dan budaya organisasi, lebih cenderung bersifat unik sehingga lebih sulit direplikasi oleh pesaing (Lorenzo et al, 2018; Barney, 1991).

Mencapai keunggulan kompetitif yang berkelanjutan merupakan literatur yang menjadi fokus dalam manajemen strategis dan pemasaran strategis. Pandangan berbasis sumber daya menawarkan ahli strategi cara mengevaluasi faktor-faktor potensial yang dapat digunakan untuk memberikan keunggulan kompetitif. Wawasan utama yang muncul dari persepektif sumber daya adalah bahwa tidak semua sumber daya memiliki kepentingan yang sama dan juga tidak semua memiliki potensi untuk menjadi sumber daya yang unggul dan kompetitif secara berkelanjutan. Keberlanjutan dari setiap keunggulan kompetitif tergantung pada sejauh mana sumber daya dapat ditiru atau diganti. Collins (2020) dan Collis \& Montgomoery (1995) menunjukkan bahwa memahami hubungan sebab akibat antara sumber keunggulan dan kesuksesan strategi bisa sangat sulit dalam praktiknya. Dengan demikian, banyak upaya manajerial harus diinvestasikan dalam mengidentifikasi, memahami dan mengklasifikasikan kompetensi inti. Selain itu, manajemen harus berinvestasi dalam pembelajaran organisasi untuk memelihara dan mengembangkan sumberdaya dan kompetensi utama.

Dalam pandangan berbasis sumber daya, ahli strategi memilih strategi atau posisi kompetitif yang paling mengeksploitasi sumber daya dan kemampuan internal relatif terhadap peluang eksternal. Mengingat bahwa sumber daya strategis mewakili jaringan kompleks aset dan kemampuan yang saling terkait, organisasi 
dapat mengadopsi banyak posisi kompetitif yang mungkin. Meskipun teori ini telah menjelaskan berbagai pedoman yang dapat dilakukan oleh perusahaan agar mampu memaksimalkan kinerja sumber daya namun studi ini menganggap bahwa sampai saat ini implementasi dari Resource Based Theory masih kurang efektif. Hal ini diadasari oleh berbagai macam fenomena baik penelitian terdahulu maupun dalam dunia bisnis, sehingga studi ini menganggap bahwa strategi perang Badar merupakan strategi yang relevan dan dapat mendukung implementasi Resource Based Theory karena menitikberatkan pada pemanfaatan sumber daya sama seperti yang dilakukan Rasulullah ketika menerapkan strategi perang yang mana strategi ini juga dapat diterapkan pada perusahaan.

\section{Strategi Perusahaan}

Strategi merupakan penentuan tujuan dan sasaran jangka panjang dasar suatu perusahaan, dan penerapan tindakan dan alokasi sumber daya yang diperlukan untuk mewujudkan tujuan ini. Strategi yang dimaksud meliputi tujuan dan sasaran, dan sarana untuk pencapaian perusahaan, termasuk tindakan dan alokasi sumber daya. Strategi adalah pola dasar penyebaran sumber daya dan perencanaan saat ini dan interaksi lingkungan yang menunjukkan bagaimana organisasi akan mencapai tujuannya (Collins, 2020; Grimmer et al., 2017; Murtadho, 2017; Ittner, et al, 2003). Porter (1985) menjelaskan bahwa strategi kompetitif adalah suatu proses untuk menentukan posisi unggul dan menguntungkan dalam industri yang bertujuan untuk membangun posisi menguntungkan dan berkelanjutan dalam menghadapi pesaing yang kuat dalam industri. Hal ini dapat dicapai melalui penciptaan keunggulan kompetitif yang unik, dan strategi adalah rute menuju keunggulan kompetitif.

Penelitian terdahulu telah memberikan wawasan secara praktis bagi perusahaan mengenai berbagai alternatif strategi yang dapat diterapkan sesuai dengan kondisi dan kebutuhan perusahaan. Secara umum terdapat beberapa strategi yang telah diperkenalkan para peneliti seperti Chapman \& Andersson (2017) yaitu strategi berbasis inovasi produk yang mana pada kondisi ini perusahaan mampu mengembangkan produk yang ditawarkan baik penciptaan produk baru, pengembangan produk, atau menciptakan produk substitusi. Strategi berbasis keberlanjutan yaitu melakukan aktivitas yang berkaitan dengan sosial, lingkungan dan tatakelola sebagai bentuk pertanggungjawaban pada stakeholder secara umum 
baik pemegang saham maupun masyarakat umum (Barron \& Chou, 2017).

Collins (2020) lebih mempertimbangkan strategi berbasis sumberdaya manusia dengan cara meningkatkan kemampuan sumberdaya manusia melalui berbagai macam pelatihan dan pengembangan kemampuan secara akademis dan teknis. Hasil yang diharapkan dari pengembangan sumbedaya manusia dapat memberikan keunggulan pada unit-unit bisnis. Strategi yang ditawarkan oleh Xiu et al (2017) lebih mengarah pada fleksibilitas dan inovasi pada berbagai aktivitas operasional internal perusahaan. Perusahaan mampu melihat kondisi dengan berbagai kemungkinan resiko yang akan dihadapi sehingga ketika satu strategi tidak dapat berjalan secara efektif maka perusahaan mampu mengganti strategi alternatif dengan cepat agar aktivitas dapat berjalan normal. Ittner, et al (2003) dalam penelitiannya memperkenalkan tiga strategi perusahaan dalam menghadapi ketidakpastian lingkungan yaitu, flexibility, Innovation, dan maintaining.

Wilden \& Gudergan (2017) menawarkan suatu strategi yang berfokus pada pelayanan yang maksimal keepada pelanggan, strategi ini digunakan untuk penciptaan nilai bagi pelanggan guna memberikan kepuasan terkait pelayanan yang diberikan sehingga perusahaan memiliki kepercayaan yang tinggi bagi pelanggan dan dapat berdampak pada peningkatan manfaat ekonomi. Strategi pemasaran yang diperkenalkan oleh Saepudin \& Mukarromah (2018) lebih berfokus pada bagaimana suatu organisasi atau perusahaan dapat meningkatkan perhatian masyarakat atas produk yang ditawarkan melalui media massa baik secara konvensional ataupun online, salah satunya berupa pembuatan iklan. Dengan adanya iklan yang disediakan pada berbagai media massa maka masyarakat akan mudah mengetahui dan mengakses produk yang ditawarkan.

Jika dilihat berbagai jenis strategi yang dikemukakan oleh para peneliti maka ini berarti bahwa banyak pilihan strategi yang dapat diterapkan pada perusahaan sesuai dengan kebutuhan dan kemampuan yang dimiliki masing-masing perusahaan saat ini. Meskipun literatur terdahulu telah memberikan wawasan mengenai berbagai alternatif strategi yang bisa digunakan, namun bukan berarti dapat menjadi solusi bagi perusahaan untuk mencapai tujuan. Hal ini karena perusahaan harus memilih strategi yang tepat dan sesuai dengan kemampuan, sumberdaya, dan tujuan yang akan dicapai, sehingga ini dianggap penting bagi perusahaan khususnya manajer yang mengambil keputusan strategis dan untuk 
mengakomodasi semua kebutuhan itu maka manajer perlu memiliki kemampuan yang baik secara komprehensif melihat semua kondisi tersebut dalam satu gambar besar secara konseptual agar mampu dengan mudah menentukan strategi yang paling sesuai dengan perusahaan.

\section{Strategi Perang Badar}

Perang Badar merupakan perang besar pertama yang terjadi bagi umat Islam dalam melawan kaum Quraisy, perang ini terjadi pada 17 Ramadhan tahun 2 Hijriyah (13 Maret 624) tepatnya di kota Badar yang terletak di antara provinsi Madinah dan laut merah. Kota ini memiliki ketersediaan air yang cukup banyak sehingga menarik perhatian untuk dikuasai. Rasulullah pada saat itu telah menguasai kota Madinah berupaya mempertahankan kota Madinah dengan melakukan penjagaan di sekitar lembah Badar.

Mengetahui pasukan Quraisy akan melakukan penyerangan dengan pasukan sekitar 1000 orang, Rasulullah berupaya mengatur strategi bagaimana cara mempertahankan kota Madinah. Dengan keterbatasan jumlah pasukan yang hanya sekitar 300 orang, Rasulullah memanfaatkan bukit yang terletak dekat dengan lembah Badar dengan menempatkan pasukan pemanah di bukit Badar agar setiap pasukan dapat terlihat dari jarak jauh dan mudah untuk dihalau. Meskipun pasukan sangat sedikit dibandingkan pasukan musuh, akan tetapi Rasulullah yakin dengan strategi kekompakan dan kedisiplinan yang dimiliki oleh semua pasukan mampu untuk bertahan dan mengalahkan musuh. Pasukan yang sangat disiplin dan percaya penuh terhadap komando dari Rasulullah akan memberikan dampak yang besar bagi penerapan strategi perang. Keuntungan yang dimiliki dari pasukan Rasulullah adalah karena memiliki pasukan pemanah dengan kemampuan yang sangat baik dan ditempatkan pada posisi yang sangat strategis yaitu di bukit Badar, sehingga fungsi dari pemanah tersebut akan sangat efektif menghalau musuh.

Pasukan musuh yang mulai menyerang dengan pasukan sekitar 1000 orang mulai terlihat akan memasuki dearah sekita lembah Badar. Pasukan pemanah yang mulai melihat kedatangan musuh mulai bersiap-siap untuk melakukan pertahanan dan menginfomasikan pasukan lain bersiap untuk menyerang. Pasukan musuh yang mulai mendekat mengalami kesulitan untuk menyerang akibat serangan 
pemanah yang sangat sulit dibendung karena serangan tersebut dari jarak jauh, sehingga menyebabkan banyak pasukan Quraisy berjatuhan sebelum mendekati bukit Badar, dan pada saat itu di tengah-tengah kelengahan pasukan musuh, Rasulullah dan pasukan lain melakukan penyerangan secara disiplin dan teratur dan menyebabkan pasukan musuh satu per satu gugur dan perlahan-lahan mundur dan akhirnya meninggalkan zona perang. Pada saat itulah Rasulullah memperoleh kemenangan terbesar pertamanya melawan kaum Quraisy bahkan dengan pasukan yang hanya berjumlah 300 orang mampu mengalahkan pasukan musuh sebanyak 1000 orang.

Studi ini menganggap bahwa teladan Rasulullah dalam menyikapi dan menghadapi perang memberikan semangat pada semua pasukan yang bahkan secara logis jumlah mereka tidak mampu mengimbangi jumlah pasukan musuh, akan tetapi Rasulullah dengan yakin dan percaya akan potensi yang dimiki pasukannya dan pertolongan Allah selalu menyertainya. Strategi yang diterapkan sangat efektif karena semua pasukan ditempatkan pada masing-masing kemampuannya sehingga mereka mampu memaksimalkan serangan dalam mengalahkan pasukan musuh. Tanpa melihat sebanyak apapun jumlah sumber daya yang dimiliki jika dimanfaatkan dengan baik dan yakin pada potensi serta menempatkan pada posisi tugas yang sesuai dengan potensi mereka masing-masing tentu akan memberikan hasil yang optimal.

\section{Keterkaitan Strategi Perang Badar dan Strategi Perusahaan}

Keterkaitan strategi perang Badar dan strategi perusahaan terletak pada konteks bagaimana strategi perang yang dilakukan Rasulullah dapat diterapkan pada strategi perusahaan. Pada saat Rasulullah mempersiapkan diri untuk menghadapi pasukan musuh, beliau terlebih dahulu mempelajari potensi setiap pasukan yang dimiliki dan menentukan pada posisi mana yang tepat untuk menempatkan masing-masing pasukan tersebut. Jika dikaitkan dalam konteks perusahaan, ini dapat diartikan sebagai pemanfaatan sumber daya yang dimiliki perusahaan. Manajer bertugas mengatur aktivitas perusahaan perlu memiliki kemampuan untuk mengenal karakter dan potensi sumber daya yang dimiliki perusahaan. Ketika manajer mampu mengidentifikasi dan mengenal potensi sumber daya maka hal ini dapat mendukung penerapan srategi perusahaan. 
Setelah sumber daya diidentifikasi maka perlu disesuaikan dengan lingkungan tempat perusahaan itu berada. Seperti pada masa perang, Rasulullah melihat kondisi lingkungan sekitar lembah Badar terdapat spot yang dapat digunakan untuk menghalau lawan yaitu bukit badar. Bukit tersebut dapat digunakan oleh pasukan pemanah dengan tujuan agar dapat mengawasi musuh dari jarak jauh dan dapat mengalau musuh sebelum mendekat. Dalam konteks perusahaan, manajer perlu mengenal lingkungan bisnis seperti, kondisi pasar, jenis konsumen, jenis produk, harga produk, dan lain sebagainya. Setelah mampu mengenal kondisi lingkungan maka perusahaan diharapakan mampu menyesuaikan diri melalui sumber daya yang dimiliki dengan menempatkan sesuai pada potensi dan kemampuan masingmasing. Apabila perusahaan mampu memanfaatkan sumber daya yang dimiliki, mengenal lingkungan tempat perusahaan berada, menyesuaikan potensi yang dimiliki dengan lingkungan bisnis yang akan diikuti tentunya dapat mendukung penerapan strategi perusahaan dalam mencapai tujuan.

Jika merujuk kisah perang Badar tentang strategi perang maka konteks strategi konvensional yang relevan adalah strategi yang dikembangkan oleh Collins (2020); Grimmer et al (2017); Miles, et al (1978) dan Ittner, et al (2003) yaitu strategi berbasis sumberdaya manusia, inovasi, dan pelayanan. Strategi yang dimaksud adalah bagaimana perusahaan mampu menganalisis lingkungan bisnis yang akan diikuti dan menyesuaikan sumber daya yang dimiliki agar mampu bersaing. Ketika perusahaan memiliki keterbatasan maka strategi yang digunakan adalah bertahan dengan tujuan menunggu kesempatan dan mempersiapkan diri (peningkatan sumberdaya manusia) untuk menghadapi persaingan yang lebih tinggi (Xiu et al., 2017). Pada saat perusahaan telah mampu bersaing pada level atas maka yang perlu dilakukan adalah menjaga stabilitas akitivitas perusahaan dengan menerapkan strategi inovasi. Dengan menerapkan strategi inovasi maka perusahaan mampu menghasilkan berbagai macam kebaruan dari produk yang dihasilkan dengan tujuan mampu mempertahankan kemapanan yang dimiliki saat ini, menjaga konsistensi dan endurance dalam menerapakan strategi inovasi perusahaan melalui semua sumber daya yang dimiliki. Selain itu inovasi juga dapat berupa teknologi bisnis yang diterpakan, salah satunya pengoperasian aktivitas bisnis melalui proses digital atau berbasis sistem online. Inovasi berbasis teknologi bisa dipastikan mampu memperluas jangkauan bisnis perusahaan hingga seluruh dunia. Jika perusahaan mampu menerapkan strategi tersebut maka perusahaan 
mampu menjadi leader dalam persaingan bisnis jangka panjang. Dan untuk melengkapin strategi tersebut maka perusahaan juga perlu untuk memberikan dukungan strategi yaitu berupa pelayanan yang prima bagi pengguna, dengan tujuan dapat menciptakan nilai dan kepercayaan yang tinggi bagi pengguna.

Ditinjau dari pandangan Resources Based Theory, kesesuaian strategi perang Badar dengan strategi perusahaan terletak pada optimalisasi segala sumber daya internal perusahaan. Ditinjau dari perspektif perang Badar bahwa konsep strategi yang diterapkan adalah memanfaatkan pasukan yang ada meskipun jumlahnya terbatas namun setiap pasukan ditempatkan pada posisi yang strategis sesuai dengan kemampuannya masing-masing. Apabila konsep tersebut diterapkan pada konteks perusahaan maka yang dimaksud adalah memanfaatkan dan meningkatkan sumberdaya manusia, inovasi pada berbagai proses bisnis, dan pemberian pelayanan yang maksimal pada pihak berkepentingan.

Peningkatan sumberdaya manusia dapat dilakukan dengan pemberian pelatihan teknis dan akademis agar setiap sumberdaya manusia yang ada memperoleh peningkatan kualitas pada unit bisnis masing-masing sehingga setiap unit bisnis mempunyai kemampuan untuk menciptakan nilai. Penerapan strategi dari aspek inovasi dapat berupa pengingkatan teknologi bisnis seperti mesin yang canggih atau teknologi sistem informasi yang dapat mempercepat proses aktivitas operasional perusahaan. Apabila ini dimiliki perusahaan dan belum tentu dapat ditiru oleh perusahaan lain maka bisa dipastikan dapat menungguli para pesaing dari segi kemampuan operasional. Inovasi dapat berupa penciptaan produk baru, atau mengembangkan produk yang ada dengan tujuan untuk membuktikan kepada pengguna bahwa perusahaan selalu menawarkan produk yang terbaru dan lebih baik dari produk-produk sebelumnya untuk memenuhi kepuasan pengguna. Inovasi juga dapat berupa teknologi pemasaran berbasis online, yang mana kita ketahui saat ini bahwa semua informasi bisa diakses melalui perangkat smartphone atau komputer secara sistem online. Inovasi dalam bentuk pemasaran secara online dapat mempermudah akses informasi oleh pengguna secara online apabila ingin mengetahui produk-produk yang ditawarkan sehingga akan menjadi praktis dan efisien karena pengguna tidak perlu lagi untuk mendatangi perusahaan tersebut.

Strategi pelayanan juga sangat penting untuk dipertimbangkan bagi perusahaan karena merupakan salah satu cara untuk meningkatkan kepercayaan 
dan loyalitas pengguna dalam menggunaka produk yang ditawarkan. Kepercayaan dan loyalitas pengguna tidak hanya didasarkan pada produk yang berkualitas saja, akan tetapi pemberian pelayanan justru dapat merubah minat pengguna, meskipun perusahaan menawarkan produk yang berkualitas dengan harga bersaing akan tetapi jika pelayanan yang diterima pengguna jauh dari yang diharapkan makan itu justru dapat membuat perusahaan kehilangan loyalitas pengguna dan beralih pada produk yang lain. Bentuk pelayanan yang baik dapat berupa pemberian informasi yang sangat jelas, ramah, dan solutif atas kebutuhan pengguna. Selain itu pelayanan yang baik juga dapat berupa mempermudah proses transaksi yang dapat dilakukan dimanapun dan kapanpun meskipun tidak harus mendatangi perusahaan. Ini semata-mata untuk memberikan kepuasan pengguna atas apa yang diinginkan. Oleh karena itu pemberian pelayanan yang sangat baik perlu dilakukan oleh perusahaan agar pengguna merasakan kepuasan secara personal dan akan menjadi pengguna yang loyal.

Salah satu perusahaan yang saat ini mampu bersaing dengan strategi berbasis sumber daya adalah Amazon. Amazon merupakan salah satu perusahaan teknologi multinasional terbesar di Amerika yang berfokus pada bidang bisnis e-commerce, komputasi awan, streaming digital, dan Artificial Intelegence (AI). Amazon mampu bersaing dan bahkan mengalahkan banyak perusahaan seperti Forever 21, Sears, Toys R US, Shopko, Gymboree, Charlotte Russe, Payless ShoeSource, Diesel, Thomas Cook, dan lain-lain. Satu-satunya kemampuan yang dimiliki Amazon dan belum tentu dimiliki oleh perusahaan lain adalah sumber daya berbasis teknologi yang sangat canggih seperti teknologi Artificial Intelegence (AI) berbasis online marketing. Perusahaan yang mampu menyediakan berbagai jenis produk pada pasar online dengan proses transaksi yang praktis membuat berbagai kalangan masyarakat lebih memilih produk-produk amazon dibandingkan perusahaan lain. Amazon mampu menyediakan berbagai macam produk kebutuhan masyarakat tanpa harus membangun gudang raksasa ataupun mesin pabrik yang besar tetapi hanya membutuhkan sebuah kantor yang didalamnya terdapat teknologi canggih yang mampu mengendalikan aktivitas bisnis di seluruh dunia. Kekuatan yang dimiliki adalah teknologi AI yang mampu menghubungkan berbagai aktivitas bisnis diseluruh dunia dan dapat diakses dengan mudah melalui sistem online. Pengguna diberikan kemudahan untuk memilih produk yang diingingan dan kemudahan untuk bertransaksi secara online sehingga pengguna dengan udah 
memiliki akses atas produk yang diinginkan sekalipun berada pada negara yang berbeda. Kemampuan yang dimiliki oleh Amazon sangat sulit untuk ditiru oleh pesaing apalagi pada perusahaan konvensional dengan kapasitas teknologi informasi yang bersifat umum. Ini menjadi kekuatan Amazon sehingga mampu berdiri hingga saat ini dan tidak mudah mengalami kemunduruan.

Di Indonesia juga terdapat perusahaan yang memiliki aktivitas bisnis dengan menerapkan strategi yang relevan dengan konsep srategi perang Badar yaitu Gojek. Perusahaan teknologi ini menyediakan berbagai macam jasa berbasis online seperti transportasi, jasa kebersihan, kesehatan, dan belanja kebutuhan sehari-hari. Dengan sumber daya teknologi canggih yang dimiliki, Gojek tidak perlu mengeluarkan berbagai macam investasi seperti kendaraan, alat kebersihan, gudang pertokoan, merekrut banyak karyawan, menyediakan persediaan barang dagang. Gojek hanya memanfaatkan sumber daya teknologi untuk menghubungkan pelanggan dan penyedia jasa secara online melalui aplikasi Gojek sehingga segala kebutuhan pelanggan dapat diakses melalui aplikasi tersebut. Dengan adanya aplikasi Gojek, pelanggan tidak perlu datang ke halte bus, toko swalayan, refleksi kesehatan, restoran, tapi cukup mengakses aplikasi Gojek dan jasa yang dibutuhkan akan tiba di alamat dengan perkiraan waktu yang cukup akurat.

Kehadiran Gojek di tengah masyarakat membantu aktivitas agar semakin mudah dan efisien, sehingga hal ini menyebabkan eksistensi Gojek dterima oleh masyarakat, selain itu masyarakat juga merasa aman bertransaksi karena setiap penyedia jasa dan pelanggan yang bekerjasama dengan Gojek dilakukan verifikasi data yang sangat valid sehingga mengantisipasi penipuan, apabila terjadi suatu kesalahan dalam hal transaksi yang kemugkinan berdampak merugikan maka Gojek bersedia mengganti segala kerugian baik bagi penyedia jasa maupun pelanggan.

Tokopedia dan bukalapak merupakan platform online karya anak bangsa indonesia yang bergerak dibidang perdagangan elektronik. Perusahaan ini patut menjadi kebanggaan Indonesia karena aktivitas bisnisnya tidak hanya mencakup dalam Indonesia saja tetapu juga di Asia Tenggara. Perusahaan ini memberikan kemudahan bagi setiap individu, usaha kecil dan menengah untuk melakukan aktivitas bisnis tanpa harus mengeluarkan modal usaha yang besar, cukup dilakukan secara online. Setiap pelaku usaha baik mikro, kecil, dan menengah 
(UMKM) diberi dukungan untuk mengembangkan bisnis dan produk-produk yang ditawarkan. Perusahaan ini hadir untuk memfasilitasi aktivitas bisnis para pelaku usaha agar cakupan bisnis semakin luas bahkan pada pulau yang berbeda. Strategi yang digunakan oleh perusahaan ini sama dengan Amazon yang menyediakan fasilitas bagi pelaku usaha dan individu agar dapar dengan mudah untuk melakukan jual beli secara online dengan jangkauan yang lebih luas.

Platform lainnya adalah Traveloka dan Tiket.com merupakan perusahaan berbasis online buatan anak indonesia yang bergerak dibidang jasa penjualan tiket. Strategi yang digunakan adalah berbasis teknologi informasi yang memudahkan para pengguna untuk melakukan pembelian tiket transportasi, hotel, tour wisata, dan perjalanan lainnya hanya dengan menggunakan perangkat smartphone. Perusahaan ini menciptakan suatu aplikasi yang bisa diakses pada smartphone pengguna dengan berbagai macam fitur layanan yang bisa digunakan termasuk transaksi pembayaran semua dilakukan secara online sehingga pengguna tidak lagi harus mengunjungi kantor-kantor layanan jasa tersebut.

Dari beberapa contoh perusahaan yang telah dijelaskan baik Amazon, Gojek, tokopedia, bukapalapak, traveloka, maupun tiket.com itu merupakan perusahaan yang menerapkan strategi berbasis sumber daya sama dengan strategi perang Badar yang dilakukan oleh Rasulullah. Apabila perushaan menerapakan bisnis yang secara konseptual memiliki kesamaan dengan strategi perang Badar maka tentu perusahaan akan mampu menghadapi berbagai persaingan melalui optimalisasi sumber daya yang dimiliki.

\section{Simpulan}

Studi ini bertujuan untuk memberikan wawasan tambahan mengenai strategi perang badar dan bagaimana jika strategi ini dikonseptualisasikan pada strategi perusahaan secara konvensional saat ini. Dengan menggunakan metode kualitatif deskriptif melalui tinjauan literatur terkait dengan sejarah perang badar dan strategi perusahaan secara konvensional. Berdasarkan hasil tinjauan literatur dan proses konspetualisasi pada perusahaan maka penulis menganggap bahwa strategi perang badar memiliki konseptualisasi strategi yang relevan dan bisa digunakan pada perusahaan saat ini. Strategi perang Badar merupakan strategi yang relevan apabila diterapkan pada perusahaan hingga saat ini. Strategi perang yang diterapkan 
oleh Rasulullah memilik konsep strategi perusahaan berbasis sumber daya yaitu dengan memanfaatkan segala sumberdaya internal yang dimiliki perusahaan dan sangat memungkinkan untuk ditingkatkan dari segi kapasitas dan kualitas. Esensi yang dapat diajadikan teladan adalah tentang bagaimana Rasulullah dapat memenangkan suatu peperangan yang cukup besar dengan pasukan (sumber daya) yang sangat terbatas. Ini tidak terlepas dari kemampuan Rasulullah (manajer jika pada perusahaan) dalam melihat situasi dan kondisi yang dihadapi para pasukannya pada saat perang Badar dan mampu melihat kemungkinan terburuk yang terjadi, dan pada saat itu juga mampu memutuskan strategi yang harus diterapkan sehingga pada akhirnya mampu memperoleh kemenangan yang mutlak.

Perusahaan dapat mencontoh strategi perang Badar seperti yang dilakukan Amazon, Gojek, Tokopedia, Bukalapak, Traveloka, dan Tiket.com dengan memanfaatkan sumber daya yang dimiliki, menganalisa lingkungan dan peluang bisnis, serta bagaimana mempertahankan agar strategi yang diterapkan selalu sesuai dengan pencapaian yang akan dituju bagi suatu perusahaan. Perusahaan kecil ataupun besar, memiliki sumber daya yang melimpah ataupun terbatas bukan menjadi halangan utama bagi suatu perusahaan jika mampu dimanfaatkan semaksimal mungkin sesuai dengan potensi masing-masing dan menempatkan pada posisi yang tepat sesuai dengan potensi tersebut.

Rasulullah sebagai rahmatan lilalamin bagi alam semesta dapat dijadikan teladan bagi umat manusia di muka bumi ini tidak hanya pada konteks keagamaan tetapi semua konteks kehidupan, salah satunya muamalah atau dunia bisnis. Mungkin secara sederhana bahwa sejarah perang badar hanyalah sebatas perang dan tidak memiliki relevansi dengan dunia bisnis, tetapi studi ini menemukan makna mendalam tentang esensi yang terkandung di dalamnya, yaitu sesuatu yang sangat unik bahwa strategi perang Badar memiliki makna strategi bisnis berbasis sumberdaya yang jika diterapkan pada perusahaan akan memberikan dampak positif bagi kinerja dan keberlanjutan perusahaan. 


\section{Daftar Rujukan}

Barney, J. (1991). Firm Resources and Sustained Competitive Advantage. Journal of Management, 17(1), 99-120. https://doi. org/10.1177/014920639101700108

Barron, K., \& Chou, S. Y. (2017). Toward a spirituality mode of firm sustainability strategic planning processes. Society and Business Review, 12(1), 46-62. https://doi.org/10.1108/sbr-01-2016-0008

Chapman, R., \& Andersson, T. (2017). Project strategy for product innovation: the strategic project management framework. International Journal of Project Organisation and Management, 9(4), 328. https://doi.org/10.1504/ ijpom.2017.10009330

Chong, V. K., \& Chong, K. M. (1997). Strategic choices, environmental uncertainty and SBU performance: A note on the intervening role of management accounting systems. Accounting and Business Research, 27(4), $268-276$.

Collins, C. J. (2020). Expanding the resource based view model of strategic human resource management. International Journal of Human Resource Management, O(0), 1-28. https://doi.org/10.1080/09585192.2019.1711442

Collis, D. J., \& Montgomery, C. A. (1995). Corporate Strategy. In McGraw-Hill (Vol. 16, Issue 1). McGraw-Hill.

Grimmer, L., Miles, M. P., Byrom, J., \& Grimmer, M. (2017). The Impact of Resources and Strategic Orientation on Small Retail Firm Performance. Journal of Small Business Management, 55(February 2018), 7-26. https://doi. org/10.1111/jsbm.12368

Ittner, C. D., Larcker, D. F., \& Randall, T. (2003). Performance implications of strategic performance measurement in financial services firms. Accounting, Organizations and Society, 28(7-8), 715-741.

Lorenzo, J. R. F., Rubio, M. T. M., \& Garcés, S. A. (2018). The competitive advantage in business, capabilities and strategy. What general performance factors are found in the Spanish wine industry? Wine Economics and Policy, 7(2), 94-108. https://doi.org/10.1016/j.wep.2018.04.001 
Lu, L. H., \& Huang, Y. F. (2019). Manufacturing strategy, organizational slack, and the formation of interfirm linkages. Chinese Management Studies, 13(1), 70-92. https://doi.org/10.1108/CMS-08-2017-0238

Miles, R. E., Snow, C. C., Meyer, A. D., \& Coleman, H. J. (1978). Organizational Strategy, Structure, and Process. Academy of Management Review, 3(3), $546-562$.

Murtadho, A. (2017). Strategi Pembangunan Ekonomi Yang Islami Menurut Fahim Khan. Economica: Jurnal Ekonomi Islam, 7(2), 1.

Parnell, J., \& Brady, M. (2019). Capabilities, strategies and firm performance in the United Kingdom. Journal of Strategy and Management, 12(1), 153-172. https://doi.org/10.1108/JSMA-10-2018-0107

Pasch, T. (2019). Strategy and innovation: the mediating role of management accountants and management accounting systems' use. Journal of Management Control, 30(2), 213-246.

Porter, M. E. (1985). Competitive Advantage. The Free Press, New York.

Saepudin, E., \& Cahyani, P. D. (2016). Strategi Mempersempit Ruang Gerak Rentenir Melalui Kelompok Masyarakat Berbasis Modal Sosial (Studi Kasus di Kampung Rahayu Purwokerto). ISLAMADINA. https://doi. org/10.30595/ISLAMADINA.V0I0.1326

Saepudin, E., \& Mukarromah, S. (2018). Strategi Pemasaran Perbankan Syariah di Banyumas. ISLAMADINA. https://doi.org/10.30595/islamadina. v19i2.3449

Sawarjuwono, T. (1997). Memahami Akuntansi Dalam Konteks Dimana Ia Diterapkan: Pendekatan Paradigma Bahasa. Jurnal Akuntansi Dan Auditing Indonesia, 1(1), 81-96.

Stede, W. A. Van der, Chow, C. W., \& Lin, T. W. (2006). Strategy, Choice of Performance Measures, and Performance. Behavioral Research in Accounting, 18(1), 185-205.

Wilden, R., \& Gudergan, S. (2017). Service-dominant orientation, dynamic capabilities and firm performance. Journal of Service Theory and Practice, 27(4), 808-832. https://doi.org/10.1108/JSTP-04-2016-0077 
Xiu, L., Liang, X., Chen, Z., \& Xu, W. (2017). Strategic flexibility, innovative HR practices, and firm performance: A moderated mediation model. Personnel Review, 46(7), 1335-1357. https://doi.org/10.1108/PR-09-2016-0252 